\title{
REFLEXÕES E CONCEPÇÕES SOBRE AS MÍDIAS: A POSSIBILIDADE DE ANÁLISE DOS DISCURSOS EM SALA DE AULA
}

\section{Reflexiones y concepciones sobre los medios de comunicación: la posibilidad de análisis de los discursos en sala de clase}

\author{
Camila Heimerdinger \\ Mestre em Geografia, Professora de Geografia da Educação Básica \\ camilahgeo@hotmail.com \\ Marli Terezinha Szumilo Schlosser \\ Professora da UNIOESTE/campus de Marechal C. Rondon e atua no PPGG da \\ UNIOESTE/campus de Francisco Beltrão \\ marlisch20@hotmail.com
}

Artigo recebido em 16/07/2017 e aceito para publicação em 30/11/2017

DOI: $10.12957 / \operatorname{tamoios} .2017 .29625$

\begin{abstract}
RESUMO
No artigo abordou-se as Mídias no contexto das reflexões realizadas na dissertação de mestrado intitulada: "Sentidos e significados das Mídias para alunos e professores de Geografia: estudo dos aspectos didático-pedagógicos do uso das Mídias nos municípios limítrofes de Nova Santa Rosa-PR/2015-2016" e fundamentou-se com dados do trabalho de conclusão de curso em Geografia, intitulado: "Análise do discurso da mídia para alunos e professores de Geografia em Nova Santa Rosa-PR/2013". Os estudos foram realizados no período de 2013-2017. O objetivo aqui visou analisar as Mídias na conjuntura teórica articulada no ambiente escolar com a possibilidade de desvendar seus discursos. Diante das diferentes "informações" veiculadas no cotidiano e carregadas de intencionalidades, destaca-se a possibilidade de Análise do Discurso das Mídias, que o professor tem a tarefa de apresentar aos alunos. Através do método dialético foram realizadas reflexões e discussões sobre o tema tendo como base a pesquisa bibliográfica. Os dados inseridos são de professores e alunos do $9^{\circ}$ ano de duas escolas públicas, adquiridos através da aplicação de questionários.
\end{abstract}

Palavras-chave: Mídias; Discursos; Geografia; Ensino; Análise do Discurso.

\section{RESUMEN}

En el artículo se abordó los medios de comunicación en el contexto de las reflexiones realizadas en la disertación de maestría titulada: "Los sentidos y significados de los medios de comunicación para alumnos y profesores de Geografía: estudio de los aspectos didáctico-pedagógicos del uso de los medios de comunicación en los municipios limítrofes de Nova Santa Rosa-PR/2015-2016" y se fundamentó con datos del trabajo de conclusión de curso en Geografía, titulado: "Análisis del discurso de los medios de comunicación para alumnos y profesores de Geografía en Nova Santa Rosa-PR/2013". Los estudios se realizaron en el período 2013-2017. El objetivo aquí pretendió analizar los medios de comunicación en la coyuntura teórica articulada en el ambiente escolar con la posibilidad de desvelar sus discursos. Ante las diferentes "informaciones" transmitidas en el cotidiano y cargadas de intencionalidades, se destaca la posibilidad de análisis del discurso de los medios de comunicación, que el profesor tiene la tarea de presentar a los alumnos. A través del método dialéctico se realizaron reflexiones y discusiones sobre el tema teniendo como base la investigación bibliográfica. Los datos introducidos son de profesores y alumnos del $9^{\circ}$ año de dos escuelas públicas, adquiridos a través de la aplicación de cuestionarios.

Palabras clave: Medios de comunicación; Discursos; Geografía; Enseñanza; Análisis del discurso. 


\section{INTRODUÇÃO}

Inicialmente, é interessante frisar que na contemporaneidade uma quantidade expressiva de "informações" é disseminada à população, por diferentes veículos de comunicação, como o rádio, a televisão, o jornal, a revista, sobretudo a internet e o celular que acabam incluindo várias Mídias em um aparelho/tecnologia. Os jovens e crianças têm acesso e lidam facilmente com as novas tecnologias. As Mídias são atrativas para os mesmos e estão carregadas de discursos que são construídos para privilegiar os interesses de uma minoria da sociedade.

Com o tema Mídias tem-se como objetivo refletir sobre os meios de comunicação e informação no contexto teórico, considerando a possibilidade de análise de seus discursos. Insere-se no texto a concepção de Mídias definida por alunos e professores de escolas públicas, perante a crescente convivência com as tecnologias e possíveis manipulações/distorções dos discursos pelas grandes corporações dirigidas por empresários visando o acúmulo de capital. Isso é incluso para realizar reflexões, pois a discussão é direcionada para a sala de aula, lócus de trabalho do professor com os alunos sobre os temas que possibilitam a Análise do Discurso.

Comumente as crianças assistem à televisão que é vista como um passatempo e entretenimento, envolvendo os jovens, causando um "falso bem-estar" e satisfação. Concomitantemente, os meios de comunicação contribuem para a rede logística com as propagandas a fim aumentar o consumo; além disto, apresentam "informações" de interesse político e de caráter educativo. Perante possíveis influências e manipulações, torna-se necessário investigar, embora primeiramente conceituar as Mídias. Para Bernardo (1995, p. 9, grifo meu) em um livreto do Serviço Brasileiro de Apoio às Micro e Pequenas Empresas (SEBRAE) - Mídia vem do Latim Media e denota um meio, veículo; significando meio de comunicação social como jornais, revistas, rádio, televisão, cinema, etc. e o departamento de uma agência de propaganda que pesquisa os meios e planeja as veiculações dos discursos publicitários. Juntamente é importante conceituar a Análise do Discurso que para Pêcheux (2008, p. 8) é um dispositivo de análise ou a instauração de novos gestos de leitura. Apresenta-se como uma forma de conhecimento que leva em conta o confronto.

O trabalho envolve pesquisas das autoras realizadas no Laboratório de Ensino de Geografia (LEG), inclusas no subprojeto $O$ ensino de Geografia: da teoria a prática do Programa Institucional de Bolsa de Iniciação à Docência (PIBID) e na Linha/Grupo de Pesquisa em Ensino e Práticas de Geografia (ENGEO) na Universidade Estadual do Oeste do Paraná (UNIOESTE), campus de Marechal Cândido Rondon/PR. Além do Grupo de Pesquisa e Estudo em Geografia Agrária, Epistemologia e Ensino (GPEGAEE), da Universidade Estadual de Maringá (UEM).

$\mathrm{O}$ artigo possui reflexões da pesquisa de Mestrado $^{1}$, vinculada a Linha Educação e Ensino de Geografia do Programa de Pós-graduação em Geografia da UNIOESTE, campus de Francisco Beltrão/PR. Sobretudo, tem dados do Trabalho de Conclusão de Curso $^{2}$ em Licenciatura-Geografia realizado na UNIOESTE, campus de Marechal Cândido Rondon/PR com professores de Geografia e alunos do $9^{\circ}$ ano em duas escolas do município de Nova Santa Rosa-PR. Uma das quais é o Colégio Estadual Marechal Gaspar Dutra - Ensino Fundamental e Médio (CEGD), localizado na sede da cidade mencionada e a outra é a Escola Estadual do Campo de Planalto - Ensino Fundamental (EECP), localizada no distrito de Planalto do Oeste no mesmo município. Com o método dialético foram realizadas análises no contexto teórico principalmente sobre as Mídias e a possibilidade de Análise do Discurso, tendo como base a pesquisa bibliográfica, com o estudo e reflexão de livros, artigos, dissertações, teses, etc. 
Conforme Diniz e Silva (2008, p. 11) a dialética "[...] permite ao homem ver o mundo por outra lente" e trabalha-se no sentido de realizar uma reflexão do mundo, pois "A verdade não aparece, ela está escondida nos não ditos nos interditos das relações sociais", assim justifica-se a análise do discurso (DINIZ; SILVA, 2008, p. 11). Para reflexão, insere-se alguns dados da pesquisa quantitativa e qualitativa, utilizando-se de questionários com perguntas abertas e fechadas. As questões foram dirigidas aos alunos que estavam em sala no dia determinado para a aplicação. No colégio da sede 24 alunos responderam os questionários e na escola do campo 19 alunos participaram da pesquisa. Simultaneamente cada professor (a) de Geografia das turmas respondeu um questionário desenvolvido especialmente para análise de sua concepção sobre as Mídias.

Os professores são profissionais importantes para realizarem reflexões em sala de aula com os alunos sobre os discursos das Mídias. Eles podem contribuir na formação dos cidadãos. Na educação geográfica, teoricamente, busca-se que os alunos aprendam sobre o espaço e suas inter-relações (sociedade-natureza), constatando as diversidades e desigualdades. As manipulações e distorções contribuem para que fiquem submersas ou ocultas as desigualdades sociais e segregações socioespaciais nos discursos dissipados pelos meios de comunicação. Assim, as pessoas podem não conhecer e entender o que se sucede, acreditam que vivem em situação difícil por falta de seu esforço, embora se saiba que quesitos como a infraestrutura básica em bairros pobres, que é direito da população, não são às vezes assegurados. De outro modo, há bairros ricos que recebem maior assistência da prefeitura, contando com a instalação de novos empreendimentos para a valorização da área. $\mathrm{O}$ aluno precisa estar preparado para lidar com diferentes circunstâncias, refletindo a respeito dos assuntos expostos nas redes de comunicação e no livro didático.

As Mídias podem ser introduzidas na escola como um simples meio de comunicação, um discurso em sala de aula, um meio de consumo servindo para a aprendizagem ou manipulação. Diante disto, verifica-se que a

\footnotetext{
Mídia e escola são dois espaços públicos, instâncias de socialização e de aprendizado social. Ambas exigem ritualização, produzindo efeitos a curto, médio e longo prazos. Fornecem informação imediata e de uso imediato e constroem um universo simbólico estruturado por referenciais de apreciação da realidade (BARROS FILHO, 1999, p. 26).
}

Ambos andam simultaneamente e complementam-se, podem beneficiar o aluno, mas também prejudicar. As Mídias têm poder para manipular e distorcer as "informações", conquanto possam colaborar no desenvolvimento da aprendizagem do jovem. Por isso é formidável o professor desenvolver reflexões e posteriormente debates em sala de aula com os alunos. Não se almeja criticar a prática do debate em sala de aula, mas sugere-se que se faça o uso de reflexões primordialmente. Acredita-se que o diálogo é importante inicialmente para se interagir com os alunos sobre as contradições existentes no espaço. Logo, é possível desenvolver outras atividades, como um debate, por exemplo, parte da turma representa as corporações, outra a população que não coloca em pauta os discursos veiculados pela mídia e, sobretudo, aqueles que fazem seus questionamentos considerando a realidade vigente. $O$ professor pode realizar críticas com a participação dos alunos sobre as manchetes para o encontro e debate de subjetividades, pois há discursos incompletos e/ou subjetivos visando à manipulação das pessoas segundo os interesses de seus financiadores. Diante disso, é vital que os professores reflitam sobre o aprendizado dos alunos e se preparem constantemente com planejamento, além de formação continuada para o exercício da docência. 
No artigo, primeiramente, são realizadas análises com os dados sobre as concepções de Mídias para professores de Geografia e seus alunos. O segundo momento possui considerações sobre as Mídias e seus discursos na contemporaneidade, tratando-se de suas manipulações e distorções, bem como a possibilidade de Análise do Discurso. Simultaneamente, são tecidas reflexões com fios de teóricos. Na sequência encontramse considerações da prática do professor com as Mídias e seus discursos. São apresentados os recursos que os professores utilizam em sala de aula, bem como se apreciam o envolvimento do cotidiano dos alunos para trabalhar a Geografia em sala e frisa-se a necessidade da Análise do Discurso.

\title{
O CONCEITO DE MÍDIAS PARA PROFESSORES E ALUNOS
}

As Mídias trouxeram praticidade nas relações cotidianas, perante a disponibilidade de "informações" em tempo real, apesar de pouco se questionar a veracidade dos discursos veiculados.

$\mathrm{Na}$ escola o professor pode realizar reflexões sobre as Mídias e seus discursos com os alunos, como dito questionar as afirmações veiculadas. Existem professores seguindo o livro didático, o principal material disponibilizado para trabalhar os respectivos conteúdos curriculares em sala, que é um recurso importante. Críticas são dirigidas a ele por frequentemente ser incompleto, embora seja difícil encontrar um material perfeito. Portanto, o mesmo é a base e deve ser adaptado às necessidades e objetivos do professor. Segundo Bittencourt (2013, p. 18),

\begin{abstract}
A educação, que poderia ser um instrumento essencial para a mudança da estrutura excludente do regime capitalista, torna-se justamente instrumento dos seus mais violentos processos de dominação ao fornecer os “conhecimentos" e o pessoal necessário para a manutenção da maquinaria produtiva em expansão desse sistema, gerando ainda um sistema ideológico que legitima os interesses dominantes das grandes corporações empresariais.
\end{abstract}

O que se enfatiza aqui é que o livro por si só não determina o bom desempenho do professor, mas sim a sua prática de ensino em sala com os alunos. A forma que lida com os discursos veiculados pelas Mídias e os trabalha com os alunos nas aulas de Geografia é o que tem relevância.

Nesse contexto, o artigo apresenta primeiro o significado do termo Mídias para alunos e professores para a desenvoltura do tema no ambiente escolar. Conhecer o significado e buscar entender o sentido das palavras é importante, assim é possível inteirar-se de suas intenções e/ou o que podem suscitar. Busca-se pensar sobre como os alunos podem definir as Mídias e também sobre a descrição dos professores, já que têm a possibilidade de discuti-las com os primeiros.

Entre as escolas participantes, uma localiza-se na sede e outra no campo, obtendo-se respostas de duas professoras. Ambas são formadas em Geografia, a professora do colégio da sede (professora A) leciona há mais de 10 anos e a professora da escola do campo (professora B) há 2 anos. O termo mídia foi interpretado de modo diferente pelas professoras que possuem experiências distintas.

Quando perguntado o que é mídia, a professora A definiu mídia como "[...] modernas tecnologias de comunicação". A palavra "moderna" utilizada por ela é perigosa. A cada momento uma tecnologia diferente é produzida, as Mídias lembram modernas tecnologias de comunicação, embora existam modos de comunicar que hoje não são considerados tão modernos, mas são meios de comunicação, por exemplo, o jornal que é uma mídia impressa. Não se tem conhecimento certo da origem do jornal, 
mas sabe-se que no Ocidente os antecedentes desenvolveram o Acta Diurna, publicado sob comando de Júlio César na Roma Antiga (TIPÓGRAFOS, 2014). O primeiro jornal publicado no Brasil foi a Gazeta no dia 10 de setembro de 1808 no estado do Rio de Janeiro (OPINIÃO, 2014).

Para a professora B mídia é "[...] um meio e um modo de intermediar a informação para o aluno, um instrumento e um mecanismo". É interessante a forma que a professora expôs sua opinião. A mídia é um modo de intermediar a "informação" que geralmente é conduzida para um público. Ao mesmo tempo, é um instrumento e mecanismo, conquanto faltasse a complementação do "para que", pois pode manipular as "informações" com certos propósitos. Estes propósitos são variados e definidos de acordo com o objetivo do autor, por exemplo, pode-se almejar o consumo das pessoas, a credibilidade/apoio para com certa ideologia política, econômica, cultural, social, etc., e/ou educativo. Quanto a esta questão, é necessário esboçar que a "informação" na escola é dirigida para o aluno, mas as Mídias em si veiculam geralmente seus discursos para a sociedade em geral, embora haja público alvo.

O termo mídia é definido e representado diferente pelas pessoas que possuem concepções distintas sobre as relações que se dão sobre o espaço. Por exemplo, uma pessoa que assiste frequentemente à televisão pode defini-la como mídia. Esse indivíduo pode até entender que existem outras Mídias como o rádio, o jornal, o celular, etc.; mas a televisão significa e representa a mídia. A forma de expor o conceito de mídia também ocorre de forma distinta, e os recursos/discursos podem ser confundidos ou não bem explicados devido à dificuldade de formular o conceito que é complexo. Por isso, os professores precisam pesquisar e se aperfeiçoar constantemente sobre as Mídias. A tarefa do mesmo não é "repassar o conhecimento", mas questionar juntamente com os alunos o contex to para que ocorra aprendizagem.

Quando indagado sobre o significado de mídia para os alunos do colégio da sede e da escola do campo de acordo com as alternativas disponíveis no questionário, os alunos informaram que as Mídias "São propagandas com um conjunto de meios de comunicação em massa". Houve alunos respondendo que as Mídias são "Os discursos do rádio e TV" e outros que marcaram a alternativa "Qualquer meio de comunicação". Entretanto, não se caracterizam como qualquer recurso, mas quando se trata das Mídias fala-se de um recurso ou vários. Existe possibilidade de se referir a alguma empresa que produz e veicula discursos.

Percebeu-se que, a resposta "São propagandas com um conjunto de meios de comunicação em massa" com mais adeptos nas duas instituições de ensino, realça as Mídias de modo genérico, ou seja, pode ser uma definição geral, até vaga e/ou pouco específica tornando-se duvidosa.

A partir dos dados é preciso frisar que as respostas dos alunos foram alternativas de um questionário que para o momento são suficientes, pois mostram que há diferentes pontos de vistas, encontram-se explicações rasas, além daqueles estudantes que não conseguem defini-las. As docentes como visto nas respostas, precisam ficar atentas como definem as Mídias, já que podem suscitar muitas reflexões e direcionar convicções em sala com os alunos.

Nesse contexto, mesmo trazendo dados breves, mas não insignificantes, constatou-se ao longo da pesquisa que os alunos possuem conhecimentos sobre o tema Mídias, recebem "informações" veiculadas pelas mesmas e têm contato com os meios de comunicação. "O professor de Geografia pode, assim, transformar qualquer texto mediático em um texto útil para o ensino da Geografia, desde que este seja o ponto de partida para uma reflexão em que o conhecimento geográfico seja a referência" (LEÃO; LEÃO, 2012, p. 41). 
Sob essa ótica, enquadra-se na classe de pensadores ou não pensadores, pois os discursos são preparados com cuidado pelos ideólogos conforme Chauí (1994, p. 95), ou seja, aqueles que pensam por todos. Assim,

\begin{abstract}
Os ideólogos são aqueles membros da classe dominante ou da classe média (aliada natural da classe dominante) que, em decorrência da divisão social do trabalho em trabalho material e espiritual, constituem a camada dos pensadores ou dos intelectuais. Estão encarregados, por meio da sistematização das ideias, de transformar as ilusões da classe dominante (isto é, a visão que a classe dominante tem de si mesma e da sociedade) em representações coletivas ou universais. Assim, a classe dominante (e sua aliada, a classe média) se divide em pensadores e não pensadores, ou em produtores ativos de ideias e consumidores passivos de ideias (CHAUÍ, 1994, p. 95).
\end{abstract}

Os ideólogos apresentam suas ideias como concepções de "todos", mas existe a possibilidade de Análise dos Discursos das Mídias que pode suscitar outras ideias, possibilitar ver o subscrito e/ou não dito nos discursos. Então tem-se aqueles que consomem passivamente "informações", nominadas de discursos e os que podem ser observados como pensadores, críticos e/ou analistas do discurso, no qual podem entender o discurso e deixar aflorar seu ponto de vista.

Portanto, o mestre precisa colocá-las (Mídias e seus discursos) em pauta em sala de aula, pois seus aprendizes conhecem ou possuem os celulares sofisticados, dominando-os tanto quanto, ou melhor, que os professores. Mesmo dominando o uso da ferramenta Mídias, frequentemente não têm conhecimento e/ou costume de analisar ou questionar seus discursos. É omissa ou mínima a habilidade de utilizar as Mídias e seus discursos com análises e críticas para conhecer seus propósitos.

\title{
AS MÍDIAS E SEUS DISCURSOS
}

Nas relações sociais remotas, primeiro com apropriação da natureza em si, não enfatizando que hoje não se aproprie, em seguida com as técnicas e o seu aperfeiçoamento no decorrer do tempo, foram introduzidas e são muito usadas atualmente as Mídias. Elas passaram a fazer parte do cotidiano das pessoas, além de estabelecerem o que deve ou não ser verbalizado e praticado em suas vidas. As Mídias estão se autossustentando, proporcionam a diminuição dos diálogos entre as pessoas, substituindo-os pelos bate-papos no aplicativo de celular WhatsApp. Com o tempo reduzido para encontros e discussões, não mais se reflete sobre os ocorridos nos diferentes lugares do mundo, sendo apenas reproduzido o que é veiculado pelas telas interativas.

As Mídias como meios de comunicação e/ou "informação" são veículos importantes para a sociedade ter conhecimento do que ocorre no próprio país e mundo. Segundo Costa $(2002$, p. 7) "Os meios de comunicação são hoje não apenas veículos, mas o local em que se suscitam e discutem temas polêmicos de interesse da sociedade". Esses temas muitas vezes são publicados na internet com discussões ferocíssimas que contêm a opinião do escritor. $\mathrm{O}$ autor supracitado defende seu ponto de vista, embora possam existir outras possibilidades não versadas. Segundo Orlandi (1999, p. 20) "As palavras simples do nosso cotidiano já chegam até nós carregadas de sentidos que não sabemos como se constituíram e que, no entanto, significam em nós e para nós". Assim, as pessoas são intérpretes dos discursos das Mídias e dissipam para o outro (por exemplo, através da conversa) aquilo que compreenderam e podem ter uma interpretação diferente quando se deparam com a concepção de outro indivíduo. 
É importante abordar o conceito de Mídias, já que às vezes ele não é bem interpretado. Existem vários meios de comunicação e informação, assim como discursos com princípios e intencionalidades diferenciadas. No texto se envolve todos, entretanto, na atualidade um jornal impresso para alguns pode ser pouco conhecido e por não ser acessível como o jornal online com o tempo ficar desconhecido. Pode-se ter dificuldade em determinar o que são Mídias e quando isso for feito ocorrer de forma incompleta gera interpretações equivocadas pelas pessoas. Esse conceito pode ser citado como determinado meio de comunicação (mídia) ou vários meios de comunicações (Mídias). Nesse artigo, discutem-se as Mídias em geral, que estão em consonância às Mídias educativas e/ou escolares. Não há só um meio de comunicação, mas múltiplos, tanto esteticamente quanto em aspecto funcional, veiculando "informações" de forma variada. Também há múltiplas abordagens e linhas editoriais que se comprometem com posicionamentos ideológicos, ou seja, com determinadas concepções de mundo sendo dissipadas através de discursos. Nesse sentido, é fundamental no exercício pedagógico que estas concepções editoriais/ideológicas fiquem claras para os alunos.

$\mathrm{Na}$ atualidade encontram-se diversas Mídias e discursos compondo um meio de comunicação. De tal modo, o celular não tem só a função de "ligação" e "mensagem de texto", há possibilidade de conter o rádio, a televisão e a internet que permite o acesso ao jornal, à revista, etc. No entanto, pode ser comprado por uma função específica, por exemplo, a ligação, embora as propagandas vendam seus variados desempenhos na forma de discursos. Sob influência e estímulo dos discursos das próprias Mídias as pessoas podem se interessar pelas tecnologias supersofisticadas. Lage (2002, p. 57, grifo do autor) faz um esboço das diferentes formas das Mídias veicularem suas "informações". Assim,

A mídia ou, se quiserem, o médium - pode ser presencial, com ou sem a intermediação de microfones, alto-falantes, projetores de transparências etc. Pode ser, também, representacional, quando falamos de livros, jornais, revistas, magazines, folhetos, folders, fotografias, filmes, novelas gravadas que se reprisam e exportam etc.; e, finalmente, eletrônica, se dispomos de audiência simultânea, porém dispersa, que se interliga pela instrumentação tecnológica do rádio, da televisão, da internet.

De acordo com as diferenças estéticas e de comunicação das Mídias, cresce na sociedade contemporânea a utilização e o aperfeiçoamento da mídia eletrônica. Estas últimas, bem como as outras (presencial e representacional) ${ }^{3}$ em seus discursos com determinados pontos de vista podem "convencer" a população da credibilidade do autor/escritor, embora se possa discordar. Para Charaudeau $(2009$, p. 40) o discurso está voltado para o uso das línguas, acontecendo na relação entre o escritor e o leitor. $\mathrm{O}$ mesmo autor traz dois tipos de discurso que estão voltados para seu alvo. Um deles é o Discurso Propagandista que seduz ou persuadis seu alvo. O outro é o Discurso "Informativo" que deseja repassar saber/conhecimento. Diante disto, não é todo discurso "informativo" que imprime saber, podendo ser ambíguo, dual e/ou confuso, permitindo a interpretação contrária ou diferente da situação concreta. Por isso o termo "informação" é utilizado entre aspas no decorrer do texto. A palavra em si parece demonstrar algo a contribuir, que algo novo surge para o público, alvo e/ou receptor. $\mathrm{O}$ termo "informação" se desmembrado revela a junção das palavras "informar" e "ação", ou seja, significa a comunicação de uma ação/fato/acontecimento, que resulta, por exemplo, em uma "notícia". Entretanto, "informação" por "informação" pode ser variada e distinta, com as intencionalidades de seu autor que destaca o que acredita e deixa de lado outros pontos de vistas. Um autor pode influenciar e manipular discursos, 
dependerá de quem está veiculando e como escreve/exibe as "informações", além do modo que o receptor absorve as mesmas.

Os discursos que chegam às pessoas podem estar manipulados segundo os interesses de seus produtores que têm o poder da desenvoltura do texto. Esta manipulação tratada no decorrer do texto é uma espécie de formatação de ideias e sua estética. As Mídias dissipam discursos que são produzidos minuciosamente, onde primeiramente se define o que se busca induzir nos receptores e na sequência as palavras são escolhidas para construir um texto. Esse discurso em texto oral ou escrito possui estética no sentido do uso de palavras "bonitas" pelo autor, que podem ser desconhecidas pelas pessoas, dificultando o entendimento do objetivo do discurso. Portanto, é próprio da manipulação o manejo de "informações" e ideias, consequentemente aquele que comumente não desenvolve a Análise do Discurso pode ser influenciado pelos discursos.

Os discursos têm uma instância de produção e outra de recepção. A instância de produção possui o saber e deve chamar a atenção do público. A instância de recepção deve proporcionar satisfação ao consumidor (CHARAUDEAU, 2009, p. 60). É deste modo que as mercadorias e os discursos atraem, causam prazer/satisfação às pessoas para novamente consumirem. Os discursos existentes são variados e o autor aludido classificou-os como: instância de produção e instância de recepção.

Os discursos podem ser educativos e favorecer a aprendizagem dos alunos, concomitantemente contribuir no conhecimento, quando realmente propõe-se "informar". As notícias sobre o mosquito Aedes Aegypti que transmite ao homem através da sua picada o vírus da Dengue, por exemplo, são "informações" divulgadas para a sociedade, com caráter preventivo a problemas de saúde. Porém, os discursos podem ser subjetivos quando manipulados por alguém que têm determinados objetivos, como o consumismo. Quanto aos discursos, percebe-se que as Mídias televisiva e radiofônica muitas vezes valorizam certos aspectos do campo, no sentido de rural e "esquecem" de outros também importantes.

Segundo Camacho (2009, p. 2) "O agronegócio-latifundiário-exportador tem sido considerado como símbolo da modernidade no campo, mas esconde por trás da aparência moderna, a barbárie da exclusão social e expropriação dos povos do campo que sua concentração de terra e renda provoca". É nesse sentido que as Mídias podem ser usadas a favor do agronegócio-latifundiário-exportador, seus discursos confeccionados a fim de sustentar esse sistema de reprodução do capital, diferente da agricultura camponesa que tem uma relação de equilíbrio com a natureza. Dessa maneira as Mídias podem manipular os discursos deixando-os incompletos, favorecendo quem lhes convém.

Os meios de comunicação perseguem o espetáculo da notícia predominando a visão urbana da sociedade, que ressalta a violência, o crime, a droga, o consumismo, o adolescente agressor, etc. Estes problemas não ocorrem com tanto vigor no meio rural e/ou não são divulgados pelas Mídias frequentemente (BORIN; VEIGA; ALMEIDA, 2001, p. 52).

Nesse contexto, as notícias da imprensa não explicam em termos concretos o que ocorre, mas molda discursos segundo interesses sobre o meio rural. Além disso, veicula discursos/produtos do agronegócio em favor do consumismo, esquecendo-se os malefícios, como no caso dos defensivos agrícolas. Não se discute a alteração da nomenclatura veneno por defensivo agrícola, advinda por possível questionamento das pessoas perante a palavra (veneno) ser "intensa" e deixar indícios de seu malefício à saúde humana. Neste caso, o nome "veneno" prejudicaria os objetivos das empresas, ou seja, o consumo do produto (agrotóxico) pelos agricultores e logo a mercadoria com o 
uso do veneno, por exemplo, o tomate. Considerado isso, o professor pode desenvolver reflexões em sala de aula e exercitar o espírito crítico colocando em pauta questões do campo, como os interesses do mercado, os problemas ambientais e o bem estar humano.

Uma das beneficiadas e organizadoras dos discursos disseminados pelas Mídias são as grandes corporações e/ou empresas, como a Carrefour (rede de hipermercados), a Syngenta (empresa de agrotóxicos) e Volkswagen AG (empresa de automóveis). Existem propagandas circulando o mundo com auxílio dos meios de comunicação, para que as pessoas cobicem e consumam mais e mais mercadorias. Não ocorre só o consumo de mercadorias concretas, mas ideologias e/ou "informações".

Segundo Debord (1997) há uma sociedade do espetáculo que caracteriza o modelo social moderno e está calcada na incessante expansão da racionalidade técnica ou instrumental. A mesma visa o sucesso individual, desprendido do julgamento ético e orientado pela conduta das pessoas através das leis do mercado, como se a vida tivesse se tornado um universo especulativo.

Assim, prevalece o individualismo, novos valores estão sendo introduzidos e muda o modo de vida das pessoas. Um crescente desejo pelo "corpo perfeito" devido o "culto ao corpo" veiculado pelas Mídias está aliado ao consumo de mercadorias diversas. Também se constata a ambição pelo status social e financeiro que é enfatizado nos discursos das Mídias. Este status, renovado e dissipado continuamente é cobiçado por uma parcela dos adultos, jovens e idosos. Quanto aos jovens, que em número significativo frequentam as escolas, passam a ter este ambiente como uma das passarelas da moda. Charaudeau $(2009$, p. 252) corrobora que

\footnotetext{
Para que haja manipulação, é preciso alguém (ou uma instância) que tenha a intenção de fazer crer a outro alguém (ou outra instância) alguma coisa (que não é necessariamente verdadeira), para fazê-lo pensar (ou agir) num sentido que traga proveito ao primeiro; além disso, é preciso que esse outro entre no jogo sem que o perceba.
}

Parte das pessoas é atraída pelas propagandas e deseja ter as mercadorias veiculadas pelas Mídias. Segundo Silva e Carvalho (2013, p. 21) "O que temos aqui é a constituição de um indivíduo que consome, não mais pela necessidade própria da vida, mas sim, seu inverso, no qual o consumo é tomado como sentido da própria vida". Assim, compra-se sem precisar do produto, busca-se ter o último modelo da mercadoria. Consome-se porque as Mídias querem que se consuma! De acordo com os discursos, "Consumir para se satisfazer e sentir-se bem". Os diálogos entre as famílias foram reduzidos e substituídos por uma vivência individualista, onde a satisfação é suprida pelo consumo.

As Mídias são manipuladoras manipuladas, veiculam de forma intencional ou não intencional, os discursos passam pela edição dos proprietários ou daqueles que possuem concessão das Mídias. Para Charaudeau (2009, p. 252) as Mídias manipulam de uma forma que não é proposital sempre, ao se automanipularem muitas vezes são vítimas de manipulações de instâncias exteriores. Considerando isto, o jornalista/autor pode ou não ser manipulador. Com o tempo ele desenvolve um rotineiro modo de escrever os discursos das Mídias a favor do capital. "A instância midiática é vítima de seu sistema de representação, pois em vez de efetuar a troca entre ela e o cidadão, a troca ocorre entre ela e os atores da máquina econômica, a fim de sustentar sua própria promoção [...]" (CHARAUDEAU, 2009, p. 260).

Entretanto, a manipulação em geral não é natural, porque há objetivos específicos submersos nos discursos. Logo, é intencional e pelo rotineiro modo de envolver significativa parcela dos receptores não se observa seus fins. A lógica da 
mercadoria ocorre de forma ampliada, com o propósito da relação de produção, difusão, circulação e consumo. As Mídias são importantes para propaganda e a lógica do consumo ter sequência.

As Mídias são fontes do saber para muitas pessoas, existem cidadãos que não as questionam devido a sua espetacularização, as superproduções pós-modernas que encantam e aparentam mostrar a realidade. Sob essa ótica, "Aparentemente inofensiva e ingênua, a mídia pode trabalhar para a padronização do sujeito, por meio de técnicas, estratégias de convencimento, [...]" (SOUSA, 2012, p. 928).

Para aprofundar o estudo sobre as Mídias é interessante realizar a Análise do Discurso, onde podem sobressair diferentes hipóteses das manchetes das Mídias. Nessa perspectiva,

\begin{abstract}
A análise do discurso (AD) é um campo de estudo que oferece ferramentas conceituais para a análise desses acontecimentos discursivos, na medida em que toma como objeto de estudos a produção de efeitos de sentido, realizada por sujeitos sociais, que usam a materialidade da linguagem e estão inseridos na história. Por isso, os campos da $\mathrm{AD}$ e dos estudos da mídia podem estabelecer um diálogo extremamente rico, a fim de entender o papel dos discursos na produção das identidades sociais (GREGOLIN, 2007, p. 13).
\end{abstract}

A produção dos efeitos de sentido por determinadas pessoas que comandam ou estão vinculadas às empresas das Mídias pode ser estudada por meio da Análise do Discurso. Neste caso, compreender o papel dos discursos na produção das identidades sociais é de suma importância. Acredita-se que quando a pessoa (o aluno) consegue situar-se na sociedade contemporânea percebe as construções das identidades sociais. Para a prática da Análise do Discurso em sala de aula o professor precisa de preparo, investigar continuamente o que as Mídias veiculam para a sociedade. Compreender as manipulações não é simples, mas o professor pode usar exemplos conhecidos pelos alunos para facilitar o seu entendimento, por exemplo, discutir o culto ao corpo e a importância da moda produzida para os jovens.

As pessoas podem realizar interpretações sobre os discursos veiculados pelas Mídias, embora comumente não se tenha o hábito. Para isso, precisam de instrução conhecendo a possibilidade de outros vieses que a prática da Análise do Discurso possibilita. Assim, a escola é importante, o professor tem a tarefa de colocar em pauta os discursos das Mídias, desenvolver reflexões e debates com os alunos para que tenham um espírito crítico perante possíveis e subjetivas manipulações. Caso contrário, "A educação, submetida aos parâmetros do regime capitalista se torna mais uma mercadoria disponível ao público consumidor, aos estudantes transformados em clientes do sistema de ensino" (BITTENCOURT, 2013, p. 10). Reconhece-se a vivência em um sistema que almeja o acúmulo de capital, a própria educação é comercializada, está sujeita a uma formação para o mercado de trabalho e é alienadora, não considerando primordial e/ou dando relevância às reflexões/críticas.

O aluno precisa ter conhecimentos básicos para a vida e a disciplina de Geografia, entre outras, contribuem na formação cidadã dos alunos. Por isso valoriza-se a profissão docente que tem possibilidade de refletir sobre as Mídias, bem como seus discursos dissipados para a sociedade. O professor precisa de formação continuada e fazer valer sua posição de formação da maioria das profissões, formação de cidadãos. Portanto, 
comunicação. Na medida em que a Geografia apenas anuncia o discurso mediático, estaremos abrindo mão de ser enquanto ciência (LEÃO; LEÃO, 2012, p. 42-43).

A Geografia pode (deve) se apropriar dos discursos veiculados pelas Mídias, embora necessite utilizá-los de modo crítico, ressaltando simultaneamente a Análise do Discurso, meio sugerido para se compreender as diferenças e desigualdades (des) construídas no espaço geográfico. Na Geografia objetiva-se fazer uma leitura do espaço, ou seja, refletir sobre o que as Mídias veiculam do espaço.

\section{AS MÍDIAS EM SALA DE AULA}

Para colocar em pauta o ensino da Geografia e as manipulações dos discursos veiculados pelas Mídias destacam-se as palavras de Straforini (2008, p. 56). Segundo o autor, o papel da educação e do ensino da Geografia é apresentar as condições para a constatação das contradições da sociedade no espaço, surgindo um inconformismo e outra possibilidade para a condição de vivência da sociedade. Nessa perspectiva, o ensino de Geografia é importante e por meio dele podem-se compreender as realidades no espaço, desenvolver discussões em favor das pessoas. O professor de Geografia é essencial para debater a atualidade e "A Educação para ter sentido à sociedade, necessariamente, deve possibilitar o seu entendimento no presente. É o entendimento, o desvelamento da sociedade no presente que lhe dá sentido" (STRAFORINI, 2008, p. $30)$.

A Geografia é considerada por muitos alunos e até mesmo professores de outras disciplinas (e atuando na área) uma matéria enfadonha, monótona e tediosa. Diante disso, é sugerida aos acadêmicos do curso de Geografia e outras licenciaturas a alternância/troca de práticas de ensino e utilização de recursos didáticos distintos nas aulas. Também se orienta a busca pelo aperfeiçoamento do professor, bem como o estímulo da participação dos alunos e o aproveitamento do conhecido pelos mesmos para as aprendizagens dos conteúdos nas aulas. $\mathrm{O}$ uso das Mídias, recursos dominados ou não pelos alunos, comumente são bem-vindos na prática dos professores em sala de aula, embora não se menospreze a aula tradicional teórico-expositiva, que também gera resultados satisfatórios.

Perante a necessidade de trazer metodologias e recursos diferentes nas aulas de Geografia, foi perguntado para as professoras se elas utilizam materiais distintos além do livro didático/quadro de giz e quais são eles. Houve várias alternativas e a possibilidade das professoras exibirem suas respostas. A professora do colégio da sede utiliza "TV Pendrive"; "Mapas"; "Artigos em jornal ou revista"; "Retroprojetor, Multimídia"; além de informar na opção "Outros" a utilização de "CDs de temas específicos". A professora da escola do campo informou "TV Pendrive"; "Mapas"; e "Retroprojetor, Multimídia".

Vale questionar e refletir como as professoras que fazem parte da pesquisa utilizam esses recursos em sala. No pouco tempo de observação da atuação das respectivas professoras em sala de aula detectou-se que, a professora do colégio da sede tem um método mais arbitrário, assim consegue reger a turma e fazer a aula acontecer. Embora, será que está última consegue bons resultados nas análises dos discursos das Mídias e/ou circunda o ensinar de modo tradicional? Há diferentes práticas de ensino e esta última é uma delas, no qual pode-se analisar os contextos dos discursos das Mídias. A professora da escola do campo na observação das aulas deu liberdade aos alunos em sala, no sentido de deixá-los à vontade para dialogar, diferente da professora do colégio da sede. Vale pensar, até que ponto essa liberdade é promissora, pois caso a docente 
tenha o controle de turma pode suscitar diálogos favoráveis no sentido de desvendar os discursos das Mídias. Entretanto, se essa participação tiver conversa expressiva, pode prejudicar a aula e suprimir o estudo dos diversos contextos da Geografia.

Nessa perspectiva, valem as palavras de Charaudeau (2009, p. 33), quando menciona que a "informação" pode ser a transferência de saber por uma linguagem de alguém que o possui a alguém que se presume não possuí-lo. De acordo com isso, podese refletir no sentido do receptor ser visto como uma tabula rasa e o emissor o detentor do saber. Os professores podem ter atitudes semelhantes, concebendo os alunos como tabula rasa, não aproveitando os conhecimentos das experiências vividas e atuando como detentores do saber, portanto, limitando a participação do aluno na aula.

Assim, verificou-se que as professoras utilizam materiais diferentes, mas casualmente desenvolvem algo "inovador", ou seja, não possuem hábito de projetar e colocar em prática dinâmicas/atividades distintas com ou sem o uso das Mídias. O inovador não é necessariamente a apropriação das Mídias, mas seu emprego de forma diferente. Enfim, para que serve um multimídia? Para passar um texto aos alunos? Geralmente é utilizado para apresentar trechos de textos e imagens, porque o quadro de giz exige tempo. $\mathrm{O}$ fato é que pode-se utilizar este recurso de modo rotineiro, ou seja, apresentar trechos de textos e imagens. Isso não significa que uma aula bem-sucedida não surja desta prática, mas sugere-se a alternância de metodologias e recursos. Às vezes a utilização de um objeto simples, por ser simples torna-se atrativo e interessante "fazendo a aula realmente acontecer". No caso do multimídia, por exemplo, pode ser usufruído para apresentar trechos de vídeos e desenvolver-se uma aula sem a dissipação de textos, chamar a atenção não só para o que é falado, mas ilustrado. Os alunos conhecem as Mídias, visualizam imagens com alta resolução (não se poder generalizar), consequentemente trazer uma imagem sem explorar o contexto e a história que ela refugia não proporciona mérito ao seu emprego. O uso do recurso e discurso não significa ter resultados satisfatórios. Acredita-se que há algo a mais, proveniente no professor que "se desdobra e faz a aula acontecer", superestimando as tecnologias e discursos prontos.

Logo, utilizar Mídias e discursos diferentes é interessante, embora apropriar-se por si só não é o objetivo, mas estimular a aprendizagem com o uso do recurso de modo atrativo e o esclarecimento dos discursos. É preciso desenvolver uma "ação mediadora", desdobrar a aula com as habilidades e propriedades específicas do professor. A aula geográfica acontecerá na consonância entre a teoria do professor e/ou livro didático e uma prática pedagógica que envolva os conhecimentos dos alunos. As atividades que são realizadas em sala podem fundamentar e motivar o interesse dos alunos pela Geografia, caso contrário pouco importa sua concretização, pois não fez diferença na vida dos estudantes.

Uma pergunta buscou identificar se as professoras utilizam assuntos do cotidiano para desenvolver suas aulas de Geografia e se acreditam que isso contribui na formação do aluno ou na construção do conhecimento dele. A professora A informou "Sim, muito. Mantém o aluno atualizado, aumenta seus conhecimentos, aprende a valorizar a tecnologia que trouxe as novas informações". A professora B informou "Sim, e muito! Pois trazer a realidade de fatos que acontecem diariamente e relacionar com o conteúdo, contribui para uma maior assimilação dos conteúdos com a realidade".

Nas respostas, as professoras, mencionaram usar exemplos do cotidiano nas aulas para os alunos conhecerem a Geografia. É importante associar a realidade de vida do aluno, as "informações" disseminadas pelas Mídias e a ciência geográfica. Além disso, a professora A informou contribuir na aprendizagem do objetivo da aula pelo aluno e conforme a opinião da professora B, o aluno apreende Geografia com maior 
facilidade. Nesse sentido, vale a pena aproveitar os discursos que estão no auge para discutir as manipulações, como são construídos por determinadas pessoas e veiculados pelas Mídias. No dia em os alunos chegam à sala de aula conversando sobre o que recentemente foi veiculado pelas emissoras de rádio e televisão, tem-se a oportunidade de dar sequência ao diálogo direcionando-o na perspectiva de análise dos discursos das Mídias, aproveitando ou incrementando aspectos geográficos.

É conveniente o professor meditar sobre suas metodologias colocadas em prática na sala de aula com os alunos. Visto que nas aulas expositivas com memorização, os alunos conhecem o assunto momentaneamente e com o tempo o conteúdo pode ser esquecido. A aprendizagem por meio do diálogo é sugerida, realizar reflexões sobre a Geografia do livro didático e do cotidiano. Não enfatiza-se que o livro didático indispõe o cotidiano, mas buscar trazer a Geografia o mais próximo possível do aluno é muito promissor. A aprendizagem não é a transmissão da "informação" como as Mídias fazem, é um processo interno, o professor constrói o conhecimento com os alunos. Segundo Archela e Calvente (2008, p. 3)

[...] ao pensar nas ações cognitivas citadas (perceber, lembrar, julgar, raciocinar, refletir e inferir), o professor passa a ter um papel importante na preparação e no estímulo de atividades. Nesta perspectiva, o conhecimento não é transmitido, mas depende também de um processo interno.

O professor de Geografia, em especial, tem uma tarefa importante de discutir e relacionar o homem com a natureza, assim como suas contradições no espaço com os alunos. Os jovens de hoje (alunos), serão a população adulta de amanhã. Assim, necessita-se de responsabilidade com o trabalho de ensino e aprendizagem. É possível inovar as aulas com o uso de recursos e a prática de metodologias diferentes, além de refletir sobre as "informações" veiculadas pelas Mídias. Embora, alguns quesitos fazem com que os professores não busquem se aperfeiçoar para inovar as aulas de Geografia com práticas didático-pedagógicas diferentes, por exemplo, a desvalorização da profissão que se atrela a uma série de questões. Na atual conjuntura caminha-se para a privatização da educação básica, visto que escolas estão sendo fechadas, horas-atividade reduzidas, porém os gastos com as propagandas só aumentam. Estão invertidos os investimentos do governo e os professores continuam lutando pela educação realizando reivindicações. Portanto, aquele que tem gosto pela disciplina e prática docente, compreende que pode fazer a diferença com o material que está disponível para trabalhar a Geografia. Mesmo em condições adversas, é possível desenvolver aulas atrativas para os alunos e gratificantes para o professor. Basta um pouco de criatividade! É preciso agir em favor da educação e isso pode ser feito desvendando os próprios discursos das Mídias.

Segundo Tonini e Cardoso (2014, p. 208) "O aluno passa boa parte do seu tempo conectado - quando não todo o tempo - e os professores, ainda na sua formação, deveriam ser capacitados a utilizar isso a seu favor". Para Fimon (2013, p. 20) "Os alunos precisam de conhecimento, das ferramentas, das habilidades e da competência para se comunicar, criticar, criar, se importar e contribuir, agora que a mídia toma grande parte de nossas vidas hoje". Nas escolas pesquisadas o uso do celular é proibido pelos alunos. Exceto nos casos em que o professor solicite a tecnologia para atividades educativas. Então, porque não explorar esse recurso? A ideia é aprender a usar as Mídias e não ser usado pelas tecnologias. É preciso refletir como as Mídias podem beneficiar as aulas de Geografia e não serem só o meio que alimenta o sistema capitalista vigente. 
Vários cursos de licenciatura dão relevância para o uso de tecnologias em sala de aula, embora existam professores que atuam na docência e quando tiveram aulas de práticas de ensino pouco (ou nada) se abordou sobre as Mídias. Isto porque não estavam inseridas como hoje nas relações cotidianas da sociedade. Pode-se pressupor que não tinha relevância na aula, era estimada a fala do professor com o uso do livro didático e o quadro de giz. Com relação à pesquisa, a professora A possui experiência e a professora B está no início da carreira, sendo que a primeira não teve tanto estímulo para o uso de tecnologias quando realizou a graduação em Geografia, assim como a professora B. Portanto, considerável parcela de professores como a do Colégio da sede possui formação não equivalente à realidade atual das Mídias e seus discursos. Essa é uma questão que imprescindivelmente precisa ser pensada na formação docente.

Sobretudo, "[...] o desafio mais importante na educação hoje é a transformação do papel do professor: não mais um 'sábio no palco', mas ao invés disso, um 'guia ao lado" (FIMON, 2013, p. 24). O professor deve ter uma relação mútua de aprendizagem com os alunos e estes últimos com o primeiro. A aula tem possibilidade de ocorrer com companheirismo, a sala não é mais só um lugar de voz do professor e escuta do aluno, mas ambiente para diálogos com análises sobre o espaço geográfico. O desafio é usar as Mídias e seus discursos em favor do ensino de Geografia e não simplesmente continuar reproduzindo as tecnologias e as "informações" veiculadas sem explorar suas propriedades. Portanto, o meio para se investigar é a Análise do Discurso das Mídias.

Nessa perspectiva, podem-se seguir os discursos das Mídias servindo a lógica do capital, contribuir para a sua continuidade ou questionar os discursos sobrepostos por meio de análises para compreender o subscrito, constituindo uma formação crítica. Nesse último caso, tem-se uma formação que se discute as relações sobre o espaço e busca-se entender a realidade vivida. Há dois lados da mesma moeda. Aceitar e discursar os discursos ou analisá-los e reelaborá-los. Por isso é preciso saber definir o conceito de Mídias, torna-se importante abordar as Mídias e entender a lógica envolvida. Conforme a pesquisa há alunos que não conseguem definir o conceito e quando se abordam as Mídias lembram-se das tecnologias que utilizam. Os mesmos, não imaginam o que há por trás dos discursos minuciosamente confeccionados. Assim, é importante que os professores se atualizem já que às vezes para os próprios o assunto não está claro. Sobretudo, precisam trabalhar com os alunos sobre esse assunto com tamanha relevância.

\section{CONSIDERAÇÕES FINAIS}

As Mídias aparentemente são simples, parecem informar e beneficiar a população, mas possuem complexidades, variados discursos que podem dizer mais do que simplesmente esboçam ou o leitor identifica. Segundo Njaine \& Minayo (2003, p. 128) "As questões que a discussão sobre a mídia ensejou são nevrálgicas para uma proposta de educação para valores". De tal modo, os alunos e professores podem servir as Mídias, sobretudo, as Mídias podem beneficiar os alunos e professores.

Desconfiar e questionar do que é dissipado pelos meios de comunicação são atitudes formidáveis, quando se pensa na manipulação e distorção dos discursos. $\mathrm{O}$ professor pode delinear suas aulas para que ocorram reflexões sobre os textos do livro didático e contextos das Mídias "informados" diariamente. A definição de Mídias pode não estar totalmente clara, por sua complexidade, mas o contexto vivido no mundo com as Mídias e seus discursos precisa ser entendido pelo professor. Assim, nas aulas de Geografia o aluno pode realizar análises com auxílio do professor e conhecer o mundo 
das Mídias. O aluno e o professor podem definir as Mídias, diante disso, tem-se a possibilidade de acontecer ricas aprendizagens para ambos.

Para Katuta (2009, p. 38) o processo educativo é uma relação social e vice-versa. Igualmente não há educação sem comunicação e reciprocamente. Portanto, todo processo educativo é comunicativo, sendo as linguagens essenciais para a educação. Diante disso, as diversas linguagens existentes são fundamentais para a aprendizagem da Geografia. Os discursos das Mídias podem ser motores da lógica capitalista, embora recurso e discurso também seja a chave para o entendimento e mudança da realidade encontrada. Analisar discursos, compreender as objetividades submersas não é tarefa fácil diante dos belos discursos elaborados. Por isso, as reflexões e investigações devem ser profundas com empenho do decodificador (professor e aluno). É um trabalho com caminhos variados, frequentemente ocorre com reflexão e análise que podem ser desenvolvidas com recursos, discursos e conhecimentos específicos de cada professor de Geografia.

As pesquisas sobre as Mídias e seus discursos devem ser minuciosas, da mesma forma ou sublime ao que é dissipado para a sociedade. As tecnologias têm muito para contribuir na educação pública (e particular) brasileira. As escolas estão inserindo essas tecnologias, embora necessita-se de aperfeiçoamento do professor para seu emprego. Simultaneamente, os professores formados atualmente são da geração atrelada às tecnologias e precisam aproveitar estes recursos nas investigações geográficas, pois os alunos são cativados pelas Mídias.

Portanto, não se fecha a discussão, mas conclui-se para o momento que as Mídias são influentes na sociedade e a Análise do Discurso pode provocar reflexões para entender a dinâmica submersa nas "informações" veiculadas. Logo, o professor, em especial de Geografia, tem a tarefa de apresentá-la (Análise do Discurso) ao aluno.

Os professores possuem conhecimentos sobre as Mídias e as utilizam em sala de aula, embora necessitam explorá-las colocando-as em pauta. Os alunos estão significativamente envolvidos com as Mídias e as definem como as propagandas veiculadas no conjunto dos meios de comunicação. Defende-se o uso de metodologias e recursos didáticos pelos professores para a prática com aulas dinâmicas, o desenvolvimento de reflexões sobre os discursos e imagens das Mídias para a formação de cidadãos ativos na sociedade.

\section{NOTAS}

1 - A dissertação pode ser encontrada com abordagem aprofundada sobre as Mídias em sala de aula. Ver: HEIMERDINGER, Camila. Sentidos e significados das Midias para alunos e professores de Geografia: estudo dos aspectos didático-pedagógicos do uso das Mídias nos municípios limítrofes de Nova Santa Rosa-PR/2015-2016. 2016. 230 p. Dissertação (Mestrado em Geografia) - Universidade Estadual do Oeste do Paraná, campus de Francisco Beltrão.

2 - As informações com alterações significativas têm dados do Trabalho de Conclusão de Curso em Geografia. Ver: HEIMERDINGER, Camila. Análise do discurso da mídia para alunos e professores de Geografia em Nova Santa Rosa - PR/2013. 2013. 143 p. Trabalho de Conclusão de Curso (Licenciatura em Geografia) - Universidade Estadual do Oeste do Paraná, campus de Marechal Cândido Rondon.

3 - Presencial refere-se ao uso da tecnologia como o microfone com a exposição verbal para as pessoas em um exato momento e representacional faz alusão, por exemplo, a livros, revistas e novelas que reprisam e exportam momentos vividos ou não. Ver: LAGE, Nilson. Estruturas de textos midiáticos. In: GHILARDI, Maria Inês; BARZOTTO, Valdir Heitor. Nas telas da mídia. São Paulo: Editora Alínea, 2002. p. 57-71. 


\section{REFERÊNCIAS}

ARCHELA, Rosely Sampaio; CALVENTE, Maria del Carmen M. H. Ensino de Geografia: tecnologias digitais e outras técnicas passo a passo. Londrina: EDUEL, 2008.

BARROS FILHO, Clóvis de. Mundos possíveis e mundos agendados: um estudo do uso da mídia na sala de aula. In: BARZOTTO, Valdir Heitor; GHILARDI, Maria Inês. Mídia, Educação e Leitura. São Paulo: Anhembi Morumbi: Associação de Leitura do Brasil, 1999. p. 9-37.

BERNARDO, Felippe Júnior. Mídias eletrônicas, impressas e alternativas: o que são e como utilizar. Brasília: Ed. SEBRAE, 1995.

BITTENCOURT, Renato Nunes. Educação como produto de consumo no mercado capitalista ou a negação da flama do saber na tecnocracia neoliberal. Revista Espaço Acadêmico. no 146, p. 9-19, Jul. 2013.

BORIN, Jair; VEIGA, José Eli da. (orgs.); ALMEIDA, Wellington. (texto). Brasil Rural na virada do Milênio - Encontro de Pesquisadores e Jornalistas. São Paulo: USP, 2001.

CAMACHO, Rodrigo Simão. O agronegócio latifundiário versus a agricultura camponesa: a luta política e pedagógica do campesinato. In: XIX ENCONTRO NACIONAL DE GEOGRAFIA AGRÁRIA, 2009, São Paulo, Anais... São Paulo, 2009, p. 1-34.

CHARAUDEAU, Patrick. Discurso das Mídias. São Paulo: Contexto, 2009.

CHAUÍ, Marilena de Souza. O que é ideologia. 38. ed. São Paulo: Brasiliense, 1994.

COSTA, Cristina. Ficção, comunicação e mídias. São Paulo: Cenac, 2002.

DEBORD, Guy. A sociedade do espetáculo. Rio de Janeiro: Contraponto, 1997.

DINIZ, Célia Regina; SILVA, Iolanda Barbosa da. Metodologia Científica: O método dialético e suas possibilidades reflexivas. Campina Grande; Natal: UEPB/UFRN EDUEP, 2008.

FIMON, Dragan Milinkovic. O ensino no mundo midiático: construindo uma caixa de ferramentas. Líbero, São Paulo, v. 16, n. 31, p. 17-26, jan./jun. de 2013.

GREGOLIN, Maria do Rosario. Análise do discurso e mídia: a (re) produção de identidades. Revista Comunicação Mídia e Consumo, São Paulo, v. 4, n. 11, p. 11-25, 2007.

KATUTA, Ângela Massumi. Geografia, linguagens e mídia impressa. In: KATUTA, Ângela Massumi et al. Geografia e mídia impressa. Londrina: Moriá, 2009, p. 37-57. 
LAGE, Nilson. Estruturas de textos midiáticos. In: GHILARDI, Maria Inês;

BARZOTTO, Valdir Heitor. Nas telas da mídia. São Paulo: Editora Alínea, 2002. p. 5771.

LEÃO, Vicente de Paula; LEÃO, Inês de Carvalho. Ensino de geografia e mídia: linguagens e práticas pedagógicas. $2^{\mathrm{a}}$ ed. Belo Horizonte: Fino Traço, 2012.

NJAINE, Kathie; MINAYO, Maria Cecília de Souza. Violência na escola: identificando pistas para a prevenção. Interface - Comunic, Saúde, Educ. v. 7, n. 13, p. 119-134, ago. 2003.

OPINIÃO \& Notícia. O primeiro jornal impresso no Brasil. Disponível em: $<$ http://opiniaoenoticia.com.br/cultura/o-primeiro-jornal-impresso-no-brasil/>. Acesso em: 8 de set. 2014.

ORLANDI, Eni. Puccinelli. Análise de discurso: princípios e procedimentos. São Paulo: Pontes, 1999.

PÊCHEUX, Michel. O discurso: estrutura ou acontecimento. 5. ed. Campinas: Pontes, 2008.

SILVA, Rafael Bianchi; CARVALHO, Alonso Bezerra de. Educação e modos de subjetivação no capitalismo contemporâneo: reflexões a partir de Sygmunt Bauman. Revista Espaço Acadêmico. nº 146, p. 20-26, jul. 2013.

SOUSA, Cristiane Pereira de Morais e. Discurso e mídia: as relações de poder nas/das revistas. Revista Estudos Linguísticos, São Paulo, v. 41, n. 3, p. 926-935, set./dez. 2012. Disponível em: <http://www.gel.org.br/estudoslinguisticos/volumes/41/el.2012_v3_t02. red6.pdf>. Acesso em: 02 jun. 2015.

STRAFORINI, Rafael. Ensinar geografia: o desafio da totalidade-mundo nas séries iniciais. $2^{a}$ ed. São Paulo: Annablume, 2008.

TIPÓGRAFOS. Os jornais: a Imprensa pré-industrial. Disponível em: <http://www.tipografos.net/jor nais/pre-industrial.html>. Acesso em: 8 de Set. 2014.

TONINI, Ivaine Maria; CARDOSO, Juliana Carvalho. Os meios de comunicação, tecnologias digitais e práticas escolares de Geografia. Revista FSA, Teresina, v. 11, n. 2, art. 10, p. 186-210, abr./jun. 2014. 